\title{
Regulation of open pit slope stability in Russia
}

\author{
A Makarov SRK Consulting (Russia) Limited, Russia \\ I Livinsky SRK Consulting (Russia) Limited, Russia \\ V Spirin SRK Consulting (Russia) Limited, Russia
}

A Pavlovich Saint-Petersburg Mining University, Russia

\begin{abstract}
This article describes the development and updating of the Russian regulations for the stability of open pit slopes and waste dumps in Russia. Russian and international experience was considered and adapted to meet Russian legal structures.

The Russian Rules for the Stability of Benches and Slopes of Open Pits and Waste Dumps (Rules) are based on the outcome of the Large Open Pit (LOP) project and resulted in the Guidelines for Open Pit Slope Design (2010) edited by John Read and Peter Stacey.

Many of the largest Russian mining companies were involved in the financing of this program and a number of universities, consulting and scientific organisations were engaged in the development of the Rules.

The purpose of updating the Rules is to take advantage of current knowledge and software. The new Russian Rules summarise a wide range of requirements for geological and hydrogeological studies, stability analysis, monitoring methods, estimation and analysis of geotechnical risks, management of slope stability by developing special measures to reduce risks. Conditions for both strong and weak rock types are considered. Depending on the complexity and the stage of a mining project, specific types of studies, their minimum requirements and the analysis methods are specified in the Rules.
\end{abstract}

A key point for international readers to bear in mind is that countries using the civil code legal system (such as Russia) often require guidelines to be defined in more detail than would be typical in countries using the common law legal system (such as Australia, Canada, South Africa, and other English-speaking countries).

Keywords: Russian and international approaches, legislation, regulatory documents, methodologies, instructions, manuals, Federal Standards and Rules, slope stability, geotechnical model, parameters of slopes, benches and dumps, monitoring, geotechnical risk

\section{Introduction}

Approaches to open pit and waste dump slope design have distinct historical features in Russia associated with the scientific achievements of the Soviet period. The Russian legislation requires that the design must be reviewed by experts and approved by supervisory state bodies before open pit mining can be started and it defines the difference with international approach (Gwynn et al. 2011). These reviews are aimed to check that all regulatory documents have been complied with. An issue which has been considered in developing the approach is to seek the balance between a desire to formalise the project acceptability criteria, project economics and flexibility for local conditions.

The solution to this problem has been to develop a new document that has the status of the Russian Federal Standards and Rules in the field of industrial safety. The new document has the force of a technical law which must be followed by all entities involved in research, justification, design, review and implementation at all stages of project development. The document reflects the Russian and international experience in slope stability design and describes a range of methods for bench and slope stability analysis using modern techniques, software and technologies. In the new Federal Standards and Rules for the pit slope design, the 
government is only responsible for control of compliance with industrial safety requirements and the procedures for interaction between production and scientific specialists, designers and experts are defined.

\section{Historical background}

In the second half of the 20th century, as pit depths increased and landslides and slope failures became more frequent, systematic studies of slope stability in open pits and at waste dumps were undertaken. To facilitate these studies, state research institutes such as VNIMI, VIOGEM, Yakutniproalmaz, GIGHS, etc., were established to be responsible for the methodological justification of open pit slope stability and they conducted studies that were financed by the government.

The initial results of the studies were the Guidelines for determining the optimal slope angles for open pits and waste dumps (Fisenko 1962), prepared by VNIMI and edited by Professor GL Fisenko who made a significant contribution to the theoretical foundations of slope stability and their adaptation for engineers (Fisenko 1965).

As studies progressed, the guidelines were further updated. In 1972, VNIMI developed Methodological guidelines for determining overall slope angles, face angles and dump slope angles in open pits at the development and operation stages (Methodological Guidelines) (Fisenko 1972) and Instructions for monitoring deformations of slopes, bench faces and dump slopes in open pits and development of stability measures (Fisenko 1970). These documents were only based on the Soviet experience and studies, and did not use the international experience and results. However, many provisions of these documents are still relevant.

In 1998 VNIMI issued a further document on slope stability entitled Regulations for slope stability at open-cast coal mines (Regulations) (Fisenko \& Pustovoitova 1998). As this document was mainly focused on coal deposits, several specialists argued that it was irrelevant outside the coal industry. Nevertheless, most of the specialists were aware that the Regulations were a continuation of the Methodological Guidelines and they were used outside the coal industry.

Furthermore, whilst various organisations (mainly VNIMI) had developed numerous guidelines and instructions for open pit and waste dump slope stability, as well as geotechnical and hydrogeological requirements to justify geotechnical solutions, these documents had no legal force.

From 2000, mining companies in Russia began to use the services of reputable consulting companies to take advantage of the international experience gained over the past decades in the open pit mine design. However, the approaches they used differed from Russian methodologies developed back in the early 1970s and did not satisfy the legal requirements of the 1972 Rules. As a result, it was difficult to get governmental approval of open pit and waste dump slope designs based on modern achievements in geomechanics.

In recent years, some mining companies in Russia began to develop their own internal regulatory documents but these documents need to be approved by the Ministry of Justice individually to become legitimate. Consequently, an effort was made to develop new regulatory and methodological documents through the combined and coordinated efforts of experts, taking into account the Russian and international experience in geotechnical slope design.

\section{Development of new rules}

The need to change the regulatory framework for open pit and waste dump slope design has been repeatedly discussed at many conferences in Russia. The campaign was started at the technical session titled 'Open Pit Slope Design in the 21st Century: the time for change' at the Russian Mining and Exploration Forum Minex in 2015. CSIRO granted the Russian mining company, Polymetal, the rights to translate and publish Guidelines for open pit slope design (2010) by John Read and Peter Stacey and this was prepared and edited in Russia by Professor AB Makarov (2015).

The Guidelines have become the basis for the development of the Russian Rules for the Stability of Benches and Slopes of Open Pits and Waste Dumps (Rules). A well-known scientist, Professor Vadim Zoteev, made an 
overview and analysis of this book in terms of compliance with Russian approaches (Zoteev 2017). At the VII International Scientific-Practice Conference 'Innovations in Mine Design' in 2016, the format of the new document and the project structure to develop the Rules were defined. The Institute for the Integrated Development of the Mineral Deposits of the Russian Academy of Sciences (IPKON) was commissioned to manage the project (News at IPKON RAN 2017) under the supervision of Professor Oleg Zoteev.

To prepare the Rules, the all-Russian project called Open \& Stability was created similar to the international Large Open Pit (LOP) project. The main objective of the project is to develop the Rules that take advantage of the current knowledge and software in the field of slope design. The Rules should comply with current Russian legislation, consider Russian and international experience and be adapted to suit Russian regulatory approaches.

The technical study of the Rules commenced in 2019 with funding from Alrosa, EuroChem, PhosAgro, Lebedinsky and Mikhailovsky Mining and Processing Enterprises. SUEK provided the funds. The document was developed by specialists from universities, consulting and scientific organisations (IPKON RAN, Saint-Petersburg Mining University, SRK Consulting, JSC VIOGEM, YakutNIPROalmaz PJSC Alrosa, and IGD URO RAN). One of the most difficult aspects at the stage of the document development was the selection of its format, i.e. either a law or a guideline. Due to complexity and uncertainty of the criteria for project approval by supervisory bodies, a decision was made to develop a definite law that would be clearly interpreted and would allow a more flexible use of all modern scientific and technical achievements.

In 2019, the developers of the Rules have completed a significant amount of work. Initially, a working group was set up (Figure 1) and the first draft of the law with all appendices was developed during the next six months. The second half of the year was spent making adjustments to the document.

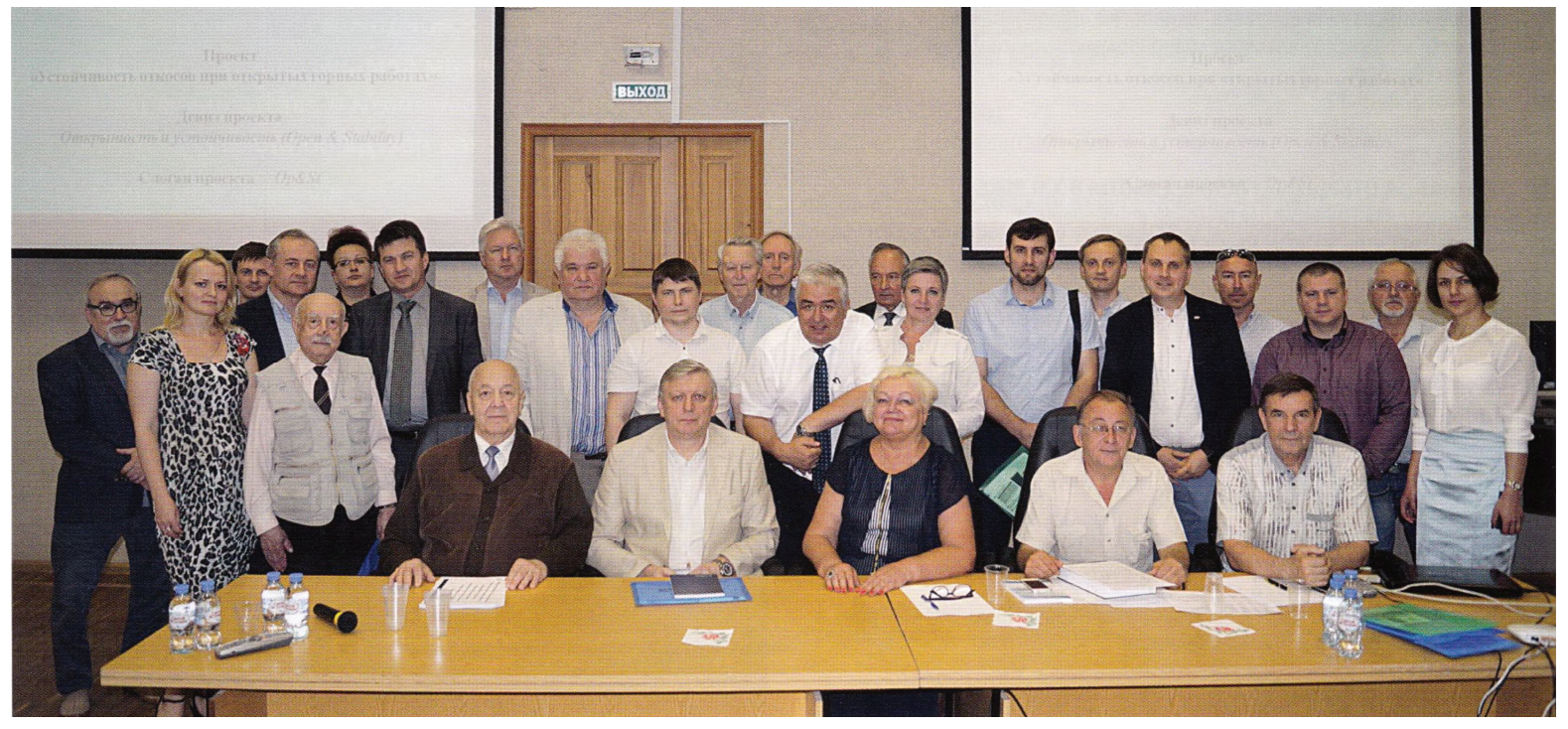

Figure 1 General photo of the first meeting on the development of the new Rules for the Stability of Benches and Slopes of Open Pits and Waste Dumps

Regular meetings and discussions of the working group were held in the IPKON RAN Institute and at various conferences: $12^{\text {th }}$ and $13^{\text {th }}$ Russian Mining and Exploration Forum Minex (Moscow 2016 and Moscow 2017, respectively), VIII International Scientific-Practice Conference Innovative Directions of Mine Design (Saint Petersburg 2017), ISRM European Rock Mechanics Symposium Eurock Geomechanics and geodynamics of rock mass (Saint Petersburg 2018), and X International Conference Combined Geotechnology: The transition to a new technological setup (Magnitogorsk 2019).

At the end of 2019, the latest version of the draft Rules was submitted to the regulatory authority in the mining industry, Rostekhnadzor. Assuming no significant comments are received, a new open pit and waste dump stability law should be enacted in the beginning of 2021, once approval is obtained from various other governmental bodies. 


\section{Contents of the new rules}

The new Rules summarise a wide range of requirements for geological and hydrogeological studies, stability analysis, monitoring methods, estimation and analysis of geotechnical risks, management of slope stability by developing special measures to reduce risks, and combined mining methods when underground excavations can influence on slope stability. At the same time, conditions for both strong and weak rock types are considered. Depending on the complexity and the stage of mining, specific types of studies, their minimum requirements and the analysis methods are specified.

A key point for international readers to bear in mind is that countries using the civil code legal system often require more specific guidelines to be defined than would be typical in countries using the common law legal system (such as Australia, Canada, South Africa, and other English-speaking countries).

The Rules provide minimum requirements for geotechnical research and are focused more on proved Russian practice and available technology. To achieve flexibility in slope optimisation and reduce risks by using international methods and any new technologies, the Rules allow use of other similar or more advanced approaches as an alternative by decision of design, consulting or mining companies.

The new document has advantages for both mining companies and design organisations.

The advantages for mining companies include:

- Development of a mine design in the form of a single document which complies with both Russian and international requirements.

- Ability to improve efficiency by applying different parameters for different pit sectors.

- Flexibility of the Rules which should allow an individual approach to each deposit.

- Ability to engage Russian specialists and companies who will be able to develop projects in-line with both international and Russian requirements.

The advantages for design institutes and companies involved in stability analysis of open pits and waste dumps include:

- Ability to make expert decisions on the selection of methodology of slope stability analysis for open pits and waste dumps.

- Use of modern equipment and software for slope stability analysis for open pits and waste dumps.

- Opportunity for specialists to gain wider experience and knowledge due to higher demand for works that use different methods.

The new Federal Standards and Rules are compared with the previous documents in the Appendix.

It is obvious that such a wide range of issues cannot be reflected in detail in one document. Therefore, the document is focused on an overview of the design and operating requirements reflected in the Rules law. The document is sufficiently flexible to take account of future trends. The Rules answer the question of what to do, and additional guidelines are being developed now to answer the question of how to do it, describing generally accepted methodological approaches:

- Guidelines for geotechnical and hydrogeological studies and mapping of rock mass.

- Guidelines for estimating slope and bench parameters of for open pits and waste dumps.

- Guidelines for monitoring of failures and managing the risks for stability of slopes and benches for open pits and waste dumps.

These guidelines are to be updated as required. 


\section{Conclusion}

The new Rules implemented at Russian mines will expand the scope of open pit mining, optimise slope and bench parameters in open pits and at waste dumps, increase the completeness of mineral extraction by open pit and combined mining methods, ensure the required level of mining safety and harmonise the Russian and international slope stability design standards. The guidelines will be updated as required to ensure that the main law reflects new technologies and study methods.

\section{Acknowledgement}

The authors would like to thank the specialists of mining companies for their painstaking work on the new Federal Standards and Rules. Special thanks to our work group:

- MR Rylnikova, IPKON RAN.

- OV Zoteev, IGD URO RAN, YakutNIPROalmaz PJSC Alrosa.

- Al Perepelitsin, independent consultant.

- EB Yanitsky, JSC VIOGEM.

- SV Tsirel, Saint-Petersburg Mining University.

- SN Kotlov, Saint-Petersburg Mining University.

- YI Kutepov, Saint-Petersburg Mining University.

- EN Yesina, IPKON RAN.

- IL Nikiforova, IPKON RAN.

- VS Fedotenko, IPKON RAN.

- AA Panzhin, IGD URO RAN.

- SN Zharikov, IGD URO RAN.

The authors would like to thank Allan McCracken, David Pearce, Esteban Hormazabal, practice leaders at SRK Consulting, for their review of this article. 


\section{Appendix Comparison of previous and new Rules}

\begin{tabular}{|c|c|c|}
\hline Compared item & $\begin{array}{l}\text { Methodological Guidelines } \\
\text { 1972, Rules 1998, Monitoring } \\
\text { Instructions } 1970\end{array}$ & $\begin{array}{l}\text { The Federal Standards and Rules of Industrial Safety } \\
\text { Rules for ensuring the stability of open pit and waste } \\
\text { dump slopes and benches } 2020\end{array}$ \\
\hline Regulatory basis & $\begin{array}{l}\text { Only Russian standards can be } \\
\text { used. }\end{array}$ & $\begin{array}{l}\text { Both Russian and international standards can be used, } \\
\text { which is very important for using proprietary and } \\
\text { international methods and software. }\end{array}$ \\
\hline \multirow[t]{4}{*}{$\begin{array}{l}\text { Document } \\
\text { format }\end{array}$} & $\begin{array}{l}\text { Guidelines with } \\
\text { recommendatory nature. } \\
\text { However, state bodies required } \\
\text { strict compliance with } \\
\text { regulatory documents in spite } \\
\text { of uncertainties in the } \\
\text { requirements. }\end{array}$ & $\begin{array}{l}\text { Federal standard mandatory for specialised } \\
\text { organisations, mining companies, and supervisory } \\
\text { authorities. Minimum set of requirements are provided } \\
\text { in clearer and flexible format. }\end{array}$ \\
\hline & $\begin{array}{l}\text { Were either developed } \\
\text { separately for coal open pits, } \\
\text { and outside of coal industry } \\
\text { their status was questionable, } \\
\text { or for all deposits the same } \\
\text { approach was used irrespective } \\
\text { of rock types and the nature of } \\
\text { deformation and disintegration } \\
\text { of rock mass in-pit walls. }\end{array}$ & $\begin{array}{l}\text { All types of deposits are considered - in strong, weak } \\
\text { and permafrost rocks; different stages of development } \\
\text { - from pre-design to operation and reconstruction. } \\
\text { Deposits are divided into hazard categories: Category II } \\
\text { (high hazard), Categories III and IV (moderate and low } \\
\text { hazard) with respective requirements for each category. }\end{array}$ \\
\hline & $\begin{array}{l}\text { Various documents had to be } \\
\text { used for justification of pit wall } \\
\text { stability, sometimes } \\
\text { contradictory or giving } \\
\text { ambiguous interpretations of } \\
\text { specific issues. }\end{array}$ & $\begin{array}{l}\text { One document contains requirements for ensuring pit } \\
\text { wall stability through a wide range of aspects: } \\
\text { - Geotechnical studies } \\
\text { - Hydrogeological studies } \\
\text { - Geomechanical model and input data } \\
\text { - Justification of stability of pit walls, benches and } \\
\text { - } \quad \text { dumps } \\
\text { - Geomechanical risk assessment and risk } \\
\quad \text { management activities }\end{array}$ \\
\hline & $\begin{array}{l}\text { Numerous proprietary } \\
\text { methodologies that were not } \\
\text { regulated and were rarely } \\
\text { implemented in practical } \\
\text { activity. }\end{array}$ & $\begin{array}{l}\text { The main requirements are set for the use of } \\
\text { mandatory methods. Alternative methods may be used } \\
\text { at discretion of operating or specialised organisation, in } \\
\text { accordance with innovative methods and technical } \\
\text { means. }\end{array}$ \\
\hline $\begin{array}{l}\text { Geotechnical } \\
\text { and } \\
\text { hydrogeological } \\
\text { studies (data } \\
\text { collection) }\end{array}$ & $\begin{array}{l}\text { No specific recommendations } \\
\text { on the list of required data and } \\
\text { the proposed methods of data } \\
\text { collection are very limited. }\end{array}$ & $\begin{array}{l}\text { Specific types of works are given, their minimal scopes } \\
\text { and obtained characteristics depending on the type, } \\
\text { complexity, hazard class and the stage of deposit } \\
\text { development. }\end{array}$ \\
\hline
\end{tabular}




\begin{tabular}{|c|c|c|}
\hline Compared item & $\begin{array}{l}\text { Methodological Guidelines } \\
\text { 1972, Rules 1998, Monitoring } \\
\text { Instructions } 1970\end{array}$ & $\begin{array}{l}\text { The Federal Standards and Rules of Industrial Safety } \\
\text { Rules for ensuring the stability of open pit and waste } \\
\text { dump slopes and benches } 2020\end{array}$ \\
\hline \multirow[b]{4}{*}{$\begin{array}{l}\text { Geotechnical } \\
\text { model }\end{array}$} & $\begin{array}{l}\text { Physical-mechanical properties } \\
\text { are defined in state standards } \\
\text { (GOST - international } \\
\text { analogues are ASTM or ISRM } \\
\text { standards) but the list of } \\
\text { required tests is not regulated. } \\
\text { There is no minimal list of } \\
\text { required parameters and the } \\
\text { stage of deposit development } \\
\text { is not accounted for. }\end{array}$ & $\begin{array}{l}\text { Specific requirements are given for required physical- } \\
\text { mechanical properties of rocks at different stages of } \\
\text { deposit development. Mandatory and recommended } \\
\text { types of tests are given depending on the stage of } \\
\text { deposit development. In case of absence of Russian } \\
\text { standards for specific tests, international standards may } \\
\text { be used. Use of reference data is allowed, or of analogy } \\
\text { method at preliminary design stage, and the use of } \\
\text { back-analysis at the stage of mining. }\end{array}$ \\
\hline & $\begin{array}{l}\text { Collection of data on } \\
\text { parameters of fractured rock } \\
\text { mass was based on the surface } \\
\text { mapping and the requirements } \\
\text { to these works were not } \\
\text { regulated. }\end{array}$ & $\begin{array}{l}\text { Collection of data on parameters of fractured rock mass } \\
\text { with the use of surface mapping, the number of } \\
\text { geomechanical boreholes (\% of the total number of } \\
\text { geological exploration holes) are regulated. Modern } \\
\text { methods of data collection are recommended } \\
\text { (photogrammetric survey). Mining companies and } \\
\text { specialised organisations can be flexible when } \\
\text { developing the program with scopes of work depending } \\
\text { on deposit specifics. }\end{array}$ \\
\hline & $\begin{array}{l}\text { Requirements for geotechnical } \\
\text { studies of foundations of waste } \\
\text { rock dumps were not } \\
\text { regulated. }\end{array}$ & $\begin{array}{l}\text { Specific requirements are given for engineering and } \\
\text { geological study of foundations of dumps, depending on } \\
\text { the foundation structure and other parameters that } \\
\text { determine the dump complexity category. }\end{array}$ \\
\hline & $\begin{array}{l}\text { No such term. Data on } \\
\text { geological structure of deposit } \\
\text { was put on geological plans } \\
\text { and cross-sections. } \\
\text { Geomechanical parameters } \\
\text { were averaged within } \\
\text { petrographic units. }\end{array}$ & $\begin{array}{l}\text { Project operators define which type of model is most } \\
\text { convenient for the deposit, and on that basis develop } \\
\text { 2D/3D models that contain geological structural } \\
\text { wireframes, rock mass properties (whether average } \\
\text { values for domains or block geotechnical model), } \\
\text { hydrogeological data, etc. }\end{array}$ \\
\hline Failure criteria & $\begin{array}{l}\text { Only Mohr-Coulomb failure } \\
\text { criteria was used: adhesion and } \\
\text { internal friction angle of rock } \\
\text { mass, and adhesion and } \\
\text { friction angle along the } \\
\text { weakening surfaces. }\end{array}$ & $\begin{array}{l}\text { Along with Mohr-Coulomb criteria, Hoek-Brown and } \\
\text { other non-linear criteria of failure can be used. Strength } \\
\text { parameters can be used as input data. }\end{array}$ \\
\hline $\begin{array}{l}\text { Approach to } \\
\text { slope design }\end{array}$ & $\begin{array}{l}\text { Proposed methodology was } \\
\text { allowed to design and justify } \\
\text { flat or convex overall slope } \\
\text { contour. Not enough attention } \\
\text { for benches stability was paid. }\end{array}$ & $\begin{array}{l}\text { Proposed methodology regulates designing pit slopes } \\
\text { by assigning optimised parameters to each element. For } \\
\text { instance, for strong rock conditions, design process can } \\
\text { start from benches optimization and overall slopes are } \\
\text { assessed afterwards. }\end{array}$ \\
\hline Stability criteria & $\begin{array}{l}\text { Safety factors, set up } \\
\text { separately for walls, benches } \\
\text { and dumps are used as stability } \\
\text { criteria. }\end{array}$ & $\begin{array}{l}\text { Two sets of criteria are considered: } \\
\text { - Factor of Safety (FoS) according to traditional } \\
\text { Russian methodology } \\
\text { - FoS and Probability of Failure (PF) according to } \\
\text { international practice }\end{array}$ \\
\hline
\end{tabular}




\begin{tabular}{|c|c|c|}
\hline Compared item & $\begin{array}{l}\text { Methodological Guidelines } \\
\text { 1972, Rules 1998, Monitoring } \\
\text { Instructions } 1970\end{array}$ & $\begin{array}{l}\text { The Federal Standards and Rules of Industrial Safety } \\
\text { Rules for ensuring the stability of open pit and waste } \\
\text { dump slopes and benches } 2020\end{array}$ \\
\hline \multirow{4}{*}{$\begin{array}{l}\text { Slope stability } \\
\text { analysis }\end{array}$} & & $\begin{array}{l}\text { The mining stage, historical knowledge, and the level of } \\
\text { geomechanical risk are taken into consideration in } \\
\text { criteria selection. Set of criteria, whether Russian or } \\
\text { international practice, can be chosen by decision of } \\
\text { design institute or specialised company. }\end{array}$ \\
\hline & $\begin{array}{l}\text { Only methods traditionally } \\
\text { used in Russia could be } \\
\text { applied, which limited the use } \\
\text { of specialised software. }\end{array}$ & $\begin{array}{l}\text { Minimal requirements are given, allowing the mining } \\
\text { company or specialised organisation to make their own } \\
\text { decisions, as to which method should be used to justify } \\
\text { the parameters of slopes depending on complexity, } \\
\text { hazard category and the project stage. }\end{array}$ \\
\hline & $\begin{array}{l}\text { The only method for pit wall } \\
\text { stability estimate was the } \\
\text { method of limit equilibrium, } \\
\text { and only its strictly specified } \\
\text { subtypes. Assessment methods } \\
\text { usually simplified with lack of } \\
\text { sophisticated quantity analysis. }\end{array}$ & $\begin{array}{l}\text { Not only classical Russian methods can be used, but also } \\
\text { methods that satisfy three equilibrium equations } \\
\text { (Spenser, Morgenstern-Price, Sarma, etc.). The groups } \\
\text { of allowable calculation methods are expanded: } \\
\text { analogy, limit equilibrium, numerical modelling, } \\
\text { probability estimates, physical modelling, etc. }\end{array}$ \\
\hline & $\begin{array}{l}\text { Slope stability at combined } \\
\text { mining method was not taken } \\
\text { into consideration. }\end{array}$ & $\begin{array}{l}\text { Factors are provided that are accounted for in } \\
\text { calculation of wall stability under combined mining. } \\
\text { Criteria of rock mass strength reduction are defined } \\
\text { depending on the category of displacement of } \\
\text { undermined material. }\end{array}$ \\
\hline \multirow[t]{4}{*}{$\begin{array}{l}\text { Bench stability } \\
\text { analysis }\end{array}$} & $\begin{array}{l}\text { Only deterministic approaches } \\
\text { to stability estimation are used. }\end{array}$ & $\begin{array}{l}\text { Using both deterministic and probabilistic approaches } \\
\text { to stability analysis. The probabilistic method is adopted } \\
\text { as additional (alternative), for a more accurate } \\
\text { consideration of the impact of uncertainty. }\end{array}$ \\
\hline & $\begin{array}{l}\text { Berm width was determined } \\
\text { only on the basis of weathering } \\
\text { and rockfall, or was adopted in } \\
\text { the design without } \\
\text { geomechanical justification. }\end{array}$ & $\begin{array}{l}\text { The width of the berm is justified both by the impact of } \\
\text { weathering and rockfall processes, and by using } \\
\text { probabilistic methods with estimating the width } \\
\text { required to intercept potential failures. }\end{array}$ \\
\hline & $\begin{array}{l}\text { The impact of blasting on the } \\
\text { rock mass strength was not } \\
\text { taken into account. }\end{array}$ & $\begin{array}{l}\text { Additional factors are introduced to reduce the strength } \\
\text { properties of rock mass or the contacts, depending on } \\
\text { the blasting conditions. }\end{array}$ \\
\hline & $\begin{array}{l}\text { Back-analysis was performed } \\
\text { only to determine strength } \\
\text { characteristics. }\end{array}$ & $\begin{array}{l}\text { Determination of shape and scale of actual failures, } \\
\text { joint spacing and length, variation of the parameters, } \\
\text { and strength characteristics for calibration against } \\
\text { actual conditions. }\end{array}$ \\
\hline \multirow[t]{2}{*}{$\begin{array}{l}\text { Groundwater is } \\
\text { considered in the } \\
\text { slope stability } \\
\text { justification }\end{array}$} & $\begin{array}{l}\text { Only one aquifer was taken } \\
\text { into account, which dictates } \\
\text { the distribution of pressure } \\
\text { heads in the rock mass. }\end{array}$ & $\begin{array}{l}\text { A complex distribution of pressure in the pit walls is } \\
\text { allowed. The possibility of considering several aquifers } \\
\text { or using a pore pressure grid for estimation. }\end{array}$ \\
\hline & $\begin{array}{l}\text { Only analytical methods } \\
\text { applied. }\end{array}$ & $\begin{array}{l}\text { Analytical calculations allowed for simple conditions. In } \\
\text { all other cases, 2D or 3D hydrogeological modelling is } \\
\text { required. }\end{array}$ \\
\hline
\end{tabular}




\begin{tabular}{l|l|l}
\hline Compared item & $\begin{array}{l}\text { Methodological Guidelines } \\
\text { 1972, Rules 1998, Monitoring } \\
\text { Instructions 1970 }\end{array}$ & $\begin{array}{l}\text { The Federal Standards and Rules of Industrial Safety } \\
\text { Rules for ensuring the stability of open pit and waste } \\
\text { dump slopes and benches 2020 }\end{array}$ \\
\hline $\begin{array}{l}\text { Stability } \\
\text { monitoring }\end{array}$ & $\begin{array}{l}\text { Stability monitoring was the } \\
\text { responsibility of the site } \\
\text { surveying department and } \\
\text { required to use only surveying } \\
\text { monitoring tools. }\end{array}$ & $\begin{array}{l}\text { For open pits of Hazard Category II, the document } \\
\text { provides for special monitoring groups to be created } \\
\text { with extended functions and a list of methods and } \\
\text { equipment to be used. The use of all modern technical } \\
\text { monitoring tools is provided for. }\end{array}$ \\
\hline $\begin{array}{l}\text { Geomechanical } \\
\text { Risk Assessment }\end{array}$ & $\begin{array}{l}\text { No risk assessment was carried } \\
\text { out. It was assumed that the } \\
\text { design parameters completely } \\
\text { exclude negative } \\
\text { consequences. }\end{array}$ & $\begin{array}{l}\text { A risk-based approach to stability analysis and } \\
\text { monitoring is introduced. For open pits of Hazard } \\
\text { Category II, the analysis and management of } \\
\text { geomechanical risks and the development of mitigation } \\
\text { measures are carried out by a special stability } \\
\text { monitoring group. }\end{array}$ \\
\hline
\end{tabular}

\section{References}

Fisenko, GL (ed.) 1962, Guidelines for determining the optimal slope angles of open pits and waste dumps, VNIMI, Leningrad. Fisenko, GL (ed.) 1965, Stability of open pit and waste dump slopes, Nedra, Moscow.

Fisenko, GL (ed.) 1972, Methodological guidelines for determination of open pit slope angles, open pit and waste dump face angles for constructed and operating mines, VNIMI, Leningrad.

Fisenko, GL (ed.) 1970, Instructions for monitoring the deformation of open pit and waste dump slopes and the development of mitigation measures, VNIMI, Leningrad.

Fisenko, GL \& Pustovoitova, TK (eds.) 1998, Rules for ensuring the slopes stability in coal open pits, VNIMI, St Petersburg.

Gwynn, XP, Ogorodnikov, S, Brown, M, McCracken, A, Mochalov, A, Norvatov, Y, ... \& Morozov, K 2011, 'Comparison between Russian Code of Practice and International Style Slope Stability Analysis', Proceedings of the International Symposium on Rock Slope Stability in Open Pit Mining and Civil Engineering Slope Stability, Canadian Rock Mechanics Association, Vancouver.

IPKON RAN 2017, 'At IPKON RAN, the first meeting was held as part of the all-Russian project for preparing a regulatory document slope stability estimation for open pits and waste dumps', Scientific, technical and production journal - Mining Industry, vol. 134, no. 4, pp. 16-17.

Makarov, AB (ed.), 2015, Руководство по проектированию бортов карьеров (Guidelines for open pit slope design), Pravoved, Ekaterinburg.

Read, J \& Stacey, P (eds.) 2010, Guidelines for open pit slope design, CSIRO Publishing, Collingwood.

Zoteev, VG 2017, 'Open pit slope design: Russian and international practice', Mining journal, vol. 2234, no. 1, pp. 85-89. 
